\title{
In-vitro Efficacy of Native Fungal Bioagents against Meloidogyne incognita
}

\author{
M. Annapurna*, B. Bhagawati and Kurulkar, Uday \\ Department of Nematology, Assam Agricultural University, Jorhat, Assam, India \\ *Corresponding author
}

\section{A B S T R A C T}

\begin{tabular}{|c|}
\hline Keywords \\
\hline $\begin{array}{l}\text { Trichoderma viride, } T . \\
\text { harzianum, } \text {, ochonia } \\
\text { chlamydosporia, } \\
\text { Purpureocillium lilacinum, } \\
\text { Meloidogyne incognita and } \\
\mathrm{LC}_{50}\end{array}$ \\
\hline Article Info \\
\hline $\begin{array}{l}\text { Accepted: } \\
04 \text { October } 2018 \\
\text { Available Online: } \\
10 \text { November } 2018\end{array}$ \\
\hline
\end{tabular}

\section{Keywords}

\section{Introduction}

Root-knot nematode attack not only more than two thousands of plant species but they caused five percent of global crop loss (Hussey and Janssen, 2002). An avoidable yield loss of tomato due to $M$. incognita was recorded to the tune of 13.20 percent in Assam (Anon., 2013). The application of chemical nematicides will become prohibited due to not only the increase of resistance in the target pathogen but also caused the environmental hazard. To reduce such causes, the use of bioagents are found increase in attention and use of such bioagents offer an effective, safe, persistent and natural durable protection against crop pest (Anita and Samiyappan, 2012). However, many natural enemies attack
Meloidogyne spp. in the soil (Kok et al., 2001) and such enemies can be used as bioagent for the effective management of Meloidogyne spp (Karssen et al., 2006). Among them, fungi are unique natural enemies for managing the nematodes in soil (Mark et al., 2010). Such fungi showed their antagonistic activity like predation, parasitism and antibiosis etc (Cayrol, 1983, Zaki, 1994 and Kalita et al., 2012) towards Meloidogyne spp. However, these fungi have ability to release the antibiotics, metabolites, protease enzymes etc. (Blaxster and Robertson, 1998 and Sharon et al., 2001) in the environment and that caused nematode viability. However, the efficacy of bioagents to reduce the nematode viability varied from species to species (Irving and Kerry, 1986). So, one of the means of 
increasing the potentiality of bioagents is to use the native biocontrol agents (Singh et al., 2013). The potential benefits and fit fall must be examined so that effective native biocontrol agent (s) can be utilized. Hence, a study was undertaken on the in-vitro efficacy of certain native fungal bioagents against M.incognita.

\section{Materials and Methods}

Source and maintenance of Meloidogyne incognita and fungal bioagents

M. incognita egg masses were obtained from Experimental plot, Department of Nematology, AAU, Jorhat-13 and pure culture were maintained on Tomato in pots in the Net house, Department of Nematology, AAU, Jorhat-13. Pure culture of biocontrol agents viz., Trichoderma viride, T. harzianum and Pochonia chlamydosporia and Purpureocillium lilacinum were obtained from Department of Plant Pathology, AAU. Jorhat13andwere maintained on PDA at P.G Laboratory, Department of Nematology AAU., Jorhat.

\section{Collection of egg masses}

Egg masses were collected from the tomato plants maintained as pure culture. Roots were dissected with a sterilized dissecting needle and egg masses were hand picked up from the galled root with help of sterilized forceps. The picked egg masses were kept in sterilized cavity block containing $2 \mathrm{ml}$ sterilized water.

\section{Surface sterilization of egg masses}

The collected egg masses were surface sterilized in 0.4 per cent sodium hypochlorite $(\mathrm{NaOCl})$ for two minutes (Singh and Mathur, 2010). Egg masses were washed thoroughly with sterile distilled water until the traces of $\mathrm{NaOCl}$ is removed and placed in cavity block for further use.

\section{Extraction of eggs from egg masses}

Surface sterilized egg masses were taken in a petridish and subjected to $0.5 \%$ sodium hypochlorite solution for two minutes, with frequent stirring followed by a 30 seconds settleling to dissolve the gelatinous matrix. The eggs released through gelatinous matrix and further disinfested in $0.4 \% \mathrm{NaOCl}$ followed by three washing with sterile water. Eggs were then collected on a 500 mesh sieve and washed thoroughly with sterilized distilled water to remove the traces of $\mathrm{NaOCl}$. A measured quantity of suspension was prepared with eggs in the distilled water in a measuring cylinder. The egg suspension was prepared in such a way that $1 \mathrm{ml}$ of it contained 100 eggs. The counting of eggs in the suspension was made by using Hawkshley counting dish. Five aliquots of $1 \mathrm{ml}$ suspension were counted and their average number was multiplied with total volume of suspension prepared.

\section{Extraction of juveniles $\left(\mathbf{J}_{2}\right)$ from eggs}

For extraction of juveniles $\left(\mathrm{J}_{2}\right)$, the sterilized eggs collected as described above were placed on a double layer facial tissue paper supported on a course aluminum wire mesh. This was placed over a $10 \mathrm{~cm}$ diameter petridish filled with required quantity of water at $24-26{ }^{\circ} \mathrm{C}$ in BOD incubator for hatching. Several such assemblies were maintained.

The juveniles collected from these were mixed together at the time of inoculation in pot experiment as also in-vitro studies. Counting of juveniles was done as described in 2.4.

\section{Cleaning and sterilization of glassware}

The glassware used for experiments were washed thoroughly with potassium dichromate $\left(\mathrm{K}_{2} \mathrm{Cr}_{2} \mathrm{O}_{7}\right)$ solutions, rinsed with water and oven dried before use and sterilized at $160^{\circ} \mathrm{C}$ for $2 \mathrm{hrs}$ in hot air oven. 


\section{Preparation of media}

\section{Potato Dextrose Agar (PDA)}

The ingredients used for preparation of PDA were peeled potato $(200 \mathrm{~g})$, dextrose $(20 \mathrm{~g})$, agar-agar $(20 \mathrm{~g})$ and distilled water $(1000 \mathrm{ml})$. Fully boiled potato extract was separated by using double layer muslin cloth and measured amount of dextrose was added to the extract. In another flask, remaining $500 \mathrm{ml}$ distilled water was taken and allowed agar-agar to melt by boiling.

The molten agar- agar was strained through double layer muslin cloth and mixed with potato extract solution. The volume was made up to $1000 \mathrm{ml}$ by adding distilled water. $\mathrm{P}^{\mathrm{H}}$ of the medium was adjusted 7.2. The medium was poured into culture tubes and conical flask plugged by non-absorbent cotton and then sterilized in autoclave at $121^{\circ} \mathrm{C}$ for 20 minutes.

\section{Potato Dextrose Broth (PDB)}

The potato dextrose broth was also prepared following the same method as describe above (2.7.1) except that no agar-agar was added.

\section{Preparation of culture filtrates of bioagents}

For the preparation of fungal culture filtrates, $100 \mathrm{ml}$ potato dextrose broth was prepared in $250 \mathrm{ml}$ Erlenmeyer flasks as mentioned in 2.7.2 above and seeded with tested fungal bioagents. The inoculated flasks were incubated at $25 \pm 2^{\circ} \mathrm{C}$ for 15 days in BOD incubator. Then fungal culture filtrates were obtained by filtering through Whatman filter paper no.1.

The filtrates so obtained were further centrifuged at 2000rpm to remove the extra spores and mycelia if any. Then supernatants were collected and used in the in-vitro studies.
Effect of fungal bioagents on the parasitism of $M$. incognita eggs

Fungal isolates were inoculated to the center of a petriplate containing PDA medium amended with antibiotic streptomycin as antibiotic at $1 \mathrm{ml} / \mathrm{L}$. At full growth, counted numbers of eggs (100) were placed on the pertiplate and incubate at $25 \pm 2^{\circ} \mathrm{C}$ for 7 days. There were four replicates for each treatment with fungal bioagent. A control treatment was maintained with eggs free plates. After 7 days of incubation the portion of the fungal growth containing eggs were collected on Hawkshely counting dish and stained with lacto phenol cotton blue. The percent egg parasitism was calculated by counting the parasitized and non-parasitized eggs under a microscope at 100 magnification using the following formula: The eggs, either infected by direct hyphal penetration or disintegration of their contents were counted as infected (Singh and Mathur, 2010), while eggs that contained juveniles and looked normal as also the eggs from which juveniles had hatched out were counted as viable.

Per cent egg parasitism $=\frac{\text { Total parsitised eggs }}{\text { Total number of eggs }} \times 100$

\section{Effect of fungal bioagents on hatch inhibition of M. incognita eggs}

To determine the effect of cell free culture filtrate on the hatching of eggs of $M$. incognita, separate experiments were carried out to evaluate the nematicidal activity of native fungal bioagents. One $\mathrm{ml}$ of each of the culture filtrate of collected isolates at 25, 50, 75 and $100 \%$ were poured into cavity block and 100 eggs were introduced into each cavity block and incubated at room temperature in completely randomized design, replicated four times. Two control treatments were maintained, one as sterilized water and second as potato dextrose broth medium. Observation 
on the number of hatched $\mathbf{J}_{2}$ in four replications (cavity block) for each treatment was determined after 7 days of incubation and for determining the hatching of eggs; test was conducted by transferring the tested eggs to sterile distilled water and observed egg hatching after $24 \mathrm{hrs}$ with the aid of stereomicroscope $(x 4)$. At the end of the experiment, number of unhatched eggs was calculated and per cent egg hatch inhibition calculated by using following formula:

Hatch inhibition of eggs $(\%)=\frac{(\text { Total number of eggs }- \text { Hatched number of eggs })}{\text { Total number of eggs }} \times 100$

Effect of culture filtrates of fungal bioagents on juvenile $\left(J_{2}\right)$ mortality of $M$. incognita

The mortality test was conducted under invitro conditions. For this, desired concentrations $(25,50,75$ and 100 percent) of culture filtrates were poured on the sterile cavity blocks containing 100 juveniles $\left(\mathrm{J}_{2}\right)$ per cavity block. Observation on juvenile mortality was recorded at 24, 48, 72 and 96 hours of exposure. Apart from the treatments with different concentration of bioagents, potato dextrose broth (PDB) and sterilized distilled water (SDW) were also maintained as controls. The test was replicated four times with two control were maintained viz., one as sterilized water and second as potato dextrose broth medium. For determining the dead nematodes revival test was conducted by transferring the immobile juveniles to sterile distilled water and observed their activities after 24hrs. The juveniles that showed no movement even when they were probed with bamboo splinter were considered dead. The corrected mortality was calculated using the formula give below.

$$
\text { Mortality }(\%)=\frac{\text { Number of dead juveniles in treatment }}{\text { Total number of juveniles in the treatment }} \times 100
$$

\section{$\mathrm{LC}_{50}$ values}

Mortality data thus obtained were subjected to 'Probit analysis' (Finney, 1952) to find out the $\mathrm{LC}_{50}$ values against each bioagent at different time of exposure.

The value of relative toxicity of bioagents was calculated as follows:

Relativetoxicity

$\frac{\text { LC } 50 \text { values of known unit }}{\text { LC50 values of other bioggents }} \times 100$ where $T$. harzianum was used as the known unit.

\section{Statistical analysis}

The percentage values were subjected arcsin transformation before analysis and data were analyzed by using statistical analysis System (SAS) and IBM SPSS (Statistical Package for the Social Sciences) 20.0 version software. DMRT test was conducted to determine the significance of treatments.

\section{Results and Discussion}

\section{Effect of fungal bioagents on the parasitism of $M$. incognita eggs}

The maximum percentage of egg parasitism was recorded in the treatment with $P$. chlamydosporia $(68.03 \%)$ followed by $P$. lilacinum (64.45\%), T. viride (43.39\%) and $T$. harzianum (39.46\%) (Table 1 and Figure 1) These treatments were significantly different from each other. However, no egg parasitism was observed in control. Further, while studying the egg parasitism, extensive network of hyphae of all the tested bioagents were detected that ramified several eggs of $M$. incognita (Figure 2). Moreover, some incubated eggs appeared abnormal, deformed and shrunken owing to the mechanical pressure exerted by the network of hyphae of the bioagents inside the eggs. Most of the 
immature eggs parasitized by bioagents and contents of the egg and embryo seemed to be disintegrated.

\section{Effect of fungal bioagents on hatching inhibition of $M$. incognita eggs}

Statistical analysis (Table 2) shows that treatments $(\mathrm{f}=18876.86, d f=5$ and $\mathrm{p} \leq$ $0.0001)$, significantly decreased egg hatching of $M$. incognita at different concentrations ( $\mathrm{f}=$ 4788.08, $d f=3$ and $\mathrm{p} \leq 0.0001)$. No egg hatch inhibition was recorded in controls (PDB and SDW). At 25 per cent concentration of culture filtrate the maximum egg hatch inhibition was recorded in $T$. harzianum $(31.45 \%)$ followed by $T$. viride $(27.61 \%)$, P. chlamydosporia (25.28\%). Minimum egg hatch inhibition was recorded with $P$. lilacinum (22.97\%). However, all the treatments were significantly different from each other. It was observed that with increase in concentrations there was increase in the egg hatch inhibition and similar trend of egg hatch inhibition as recorded at 25 per cent concentration was recorded at 50, 75 and 100 percent concentration of culture filtrates (Figure 3). The highest egg hatch inhibition to the tune of $64.16,61.69,58.05$ and 55.86 percent was recorded in $T$. harzianum, $T$. viride, $P$. chlamydosporia and $P$. lilacinum, respectively at 100 per cent concentration of culture filtrate. The interaction effect between treatment and concentration $(\mathrm{f}=487.546, d f=15$ and $\mathrm{p} \leq$ 0.0001 ) showed highly significant effect on egg hatching inhibition of $M$. incognita.

\section{Effect of fungal bioagents on mortality of M. incognita $\mathbf{J}_{2}$}

All the fungal bioagents showed significant increase in mortality of $M$. incognita $\mathrm{J}_{2}$ irrespective of concentrations of the culture filtrates as compared to the controls. No mortality of $M$. incognita $\mathrm{J}_{2}$ was recorded in controls (PDB and SDW).Statistical analysis
(Table 3) shows that all the treatments $(\mathrm{f}=$ 70980.53, $d f=5$ and $\mathrm{p}<0.0001)$, causes $\mathrm{J}_{2}$ mortality of $M$. incognita in different concentrations $(\mathrm{f}=4598.42, d f=3$ and $\mathrm{p} \leq$ $0.0001)$ at different exposure time interval $(\mathrm{f}=$ 13216.98, $d f=3$ and $\mathrm{p} \leq 0.0001)$. The concentration of culture filtrate of treatments is increased there is corresponding increasing in mortality of $\mathrm{J}_{2}$ of $M$. incognita. Among the bioagents, culture filtrate of T. harzianum was found to cause maximum mortality of $\mathrm{J}_{2}$ in all the concentrations and at different time of exposure as compared to other bioagents.

T. harzainum showed maximum mortality of $\mathrm{J}_{2}$ in 25, 50, 75 and 100 percent concentration after $96 \mathrm{hrs}$ of exposure. After T. harzianum the best bioagent was found to be $T$. viride which also caused considerably increased mortality of $\mathrm{J}_{2}$ at all the concentrations and time of than the other bioagents. However, other bioagents were also effective in causing mortality of $J_{2}$ with varying degrees at different concentrations of culture filtrates and at different exposure time.

It was observed that there was an increasing trend in mortality of $\mathrm{J}_{2}$ with increase in concentration and time of exposure in all the bioagents (Figure 4). All bioagents showed maximum mortality of $\mathbf{J}_{2}$ in 100 percent concentration of culture filtrate at all the time of exposure. The bioagents like $T$. harzianum, $T$. viride, $P$. lilacinum, $P$. chlamydosporia showed 100 percent mortality of $\mathrm{J}_{2}$ only at 100 per cent concentration and after $96 \mathrm{hrs}$ of exposure time.

The interaction effect between treatment and concentration $(\mathrm{f}=474.95, \quad d f=15$ and $\mathrm{p} \leq 0.0001)$, treatment and time $(\mathrm{f}=1403.64$, $d f=15$ and $\mathrm{p} \leq 0.0001)$, time and concentration $(\mathrm{f}=13.57, d f=9$ and $\mathrm{p} \leq 0.0001)$ and treatment $\times$ concentration $\times$ time $(\mathrm{f}=7.14, d f=45$ and $\mathrm{p} \leq 0.0001)$ showed highly significant effect on mortality of $M$. incognita $\mathbf{J}_{2}$. 
Fig.1 Effect of fungal bioagents on the parasitism of $M$. incognita eggs

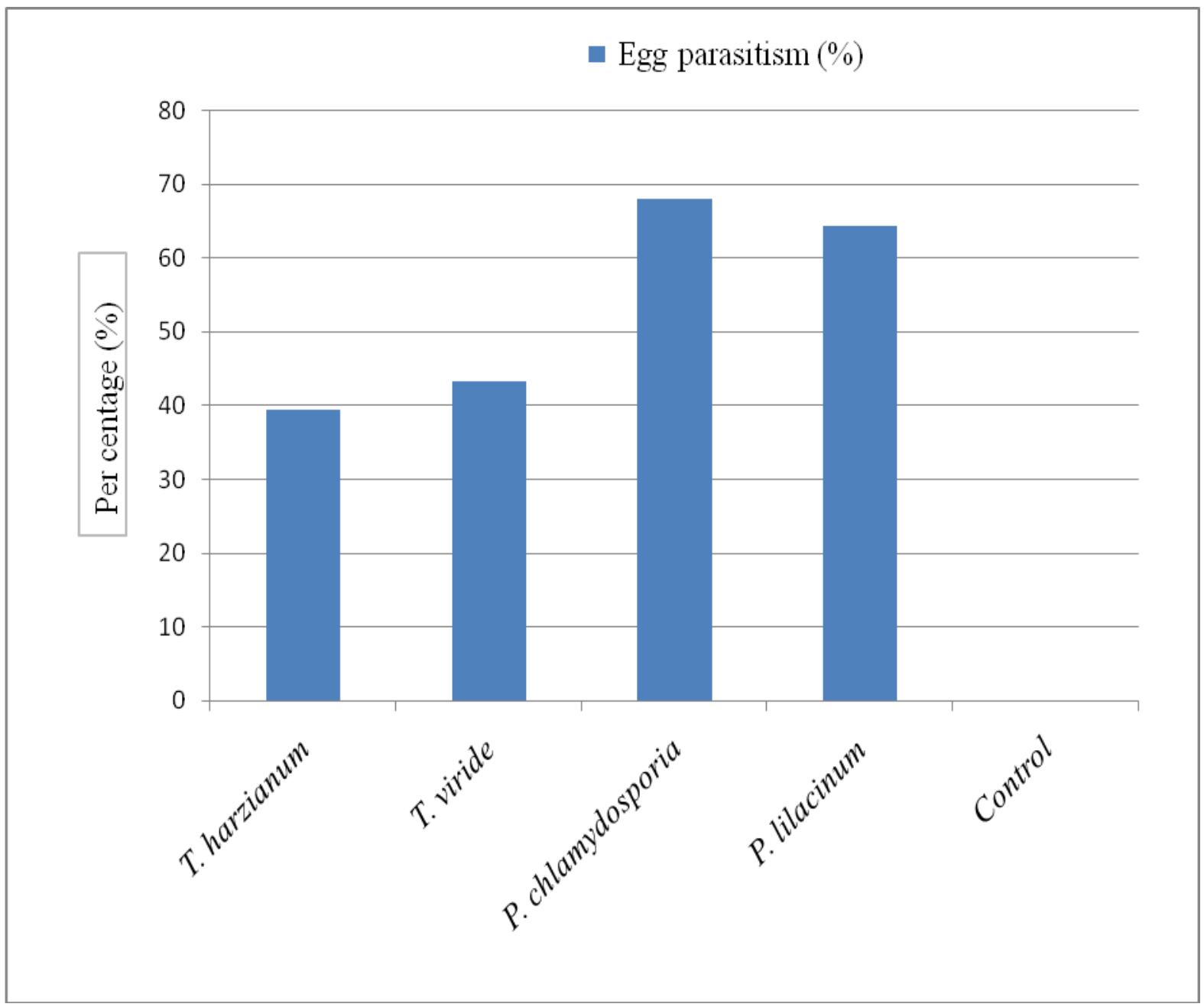

Fig.2 Parasitism of $M$. incognita eggs by fungal bioagents
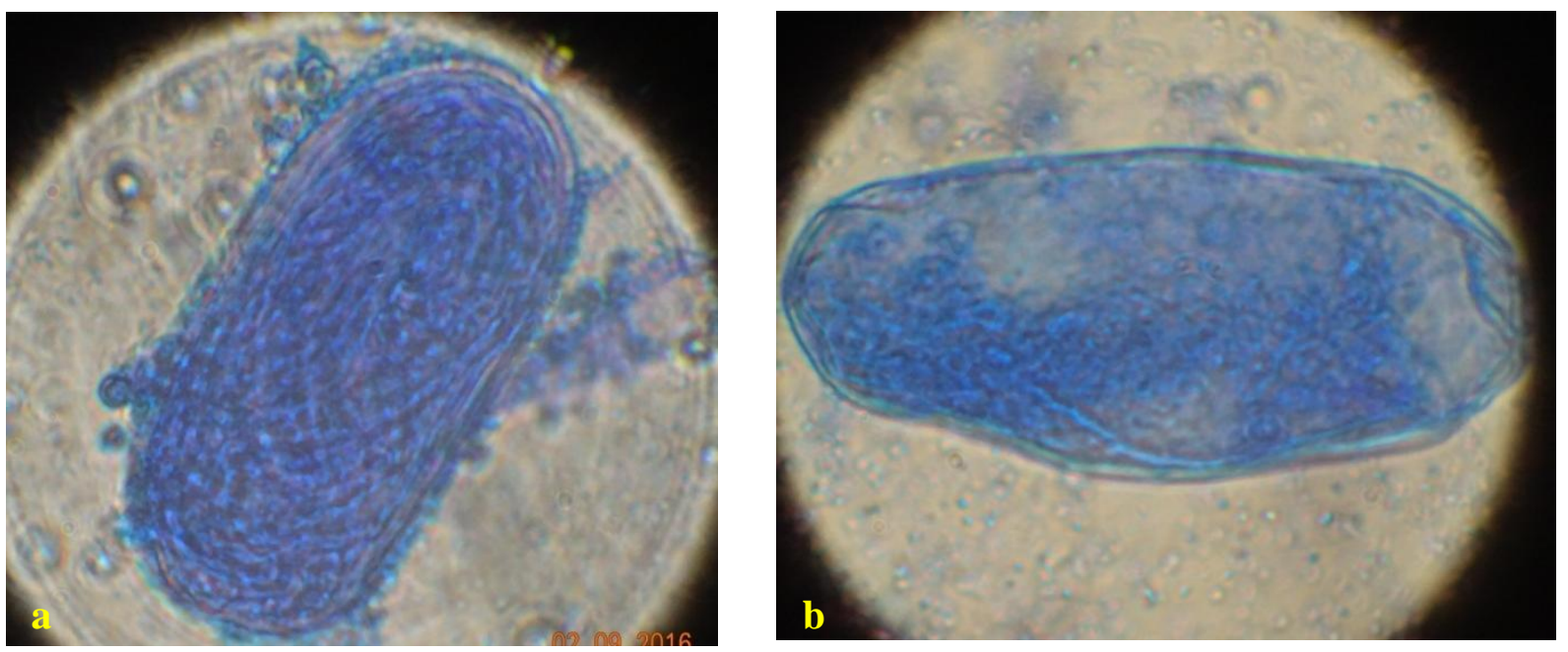

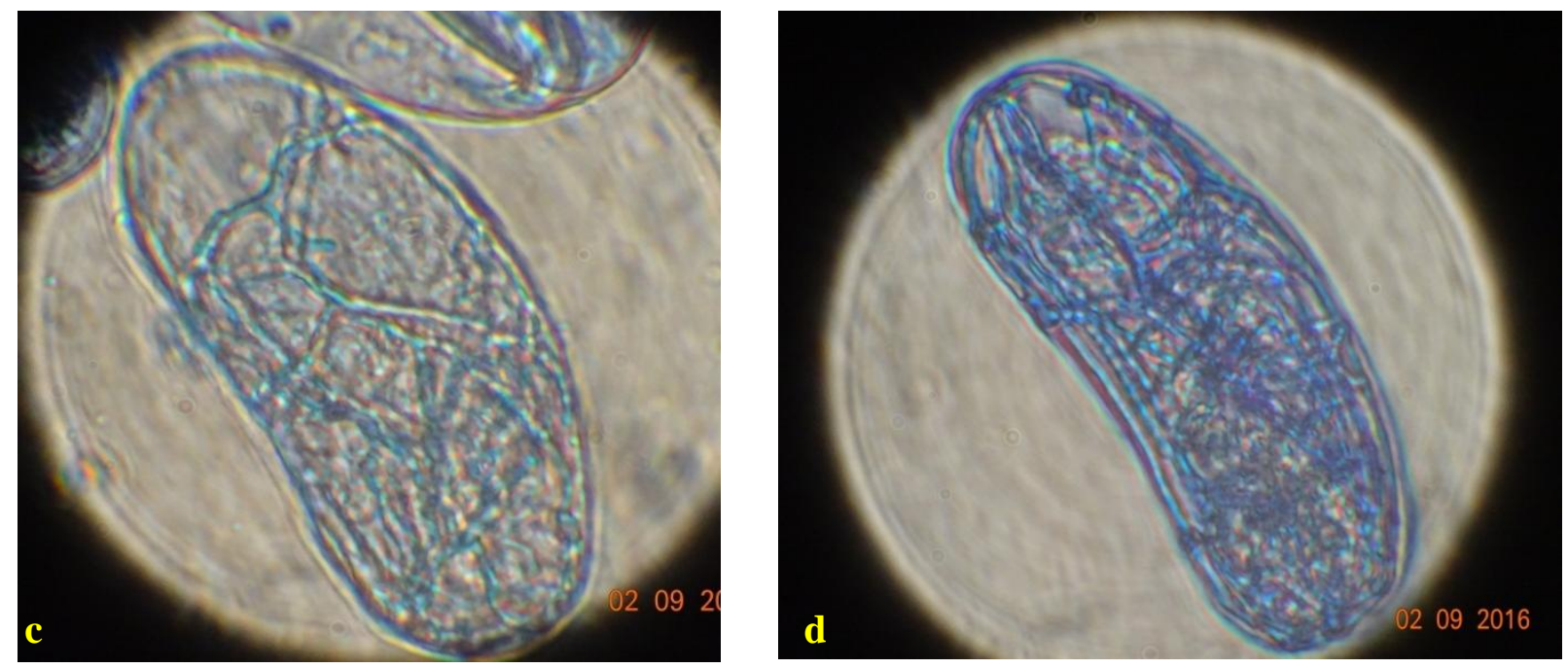

a- Egg parasitized by T. viride, b-Egg parasitized by T. harzianum, c- Egg parasitized by P. chlamydosporia, d- Egg parasitized by $P$. lilacinum.

Fig.3 Effect of culture filtrates of fungal bioagents on the hatching inhibition of $M$ incognita eggs

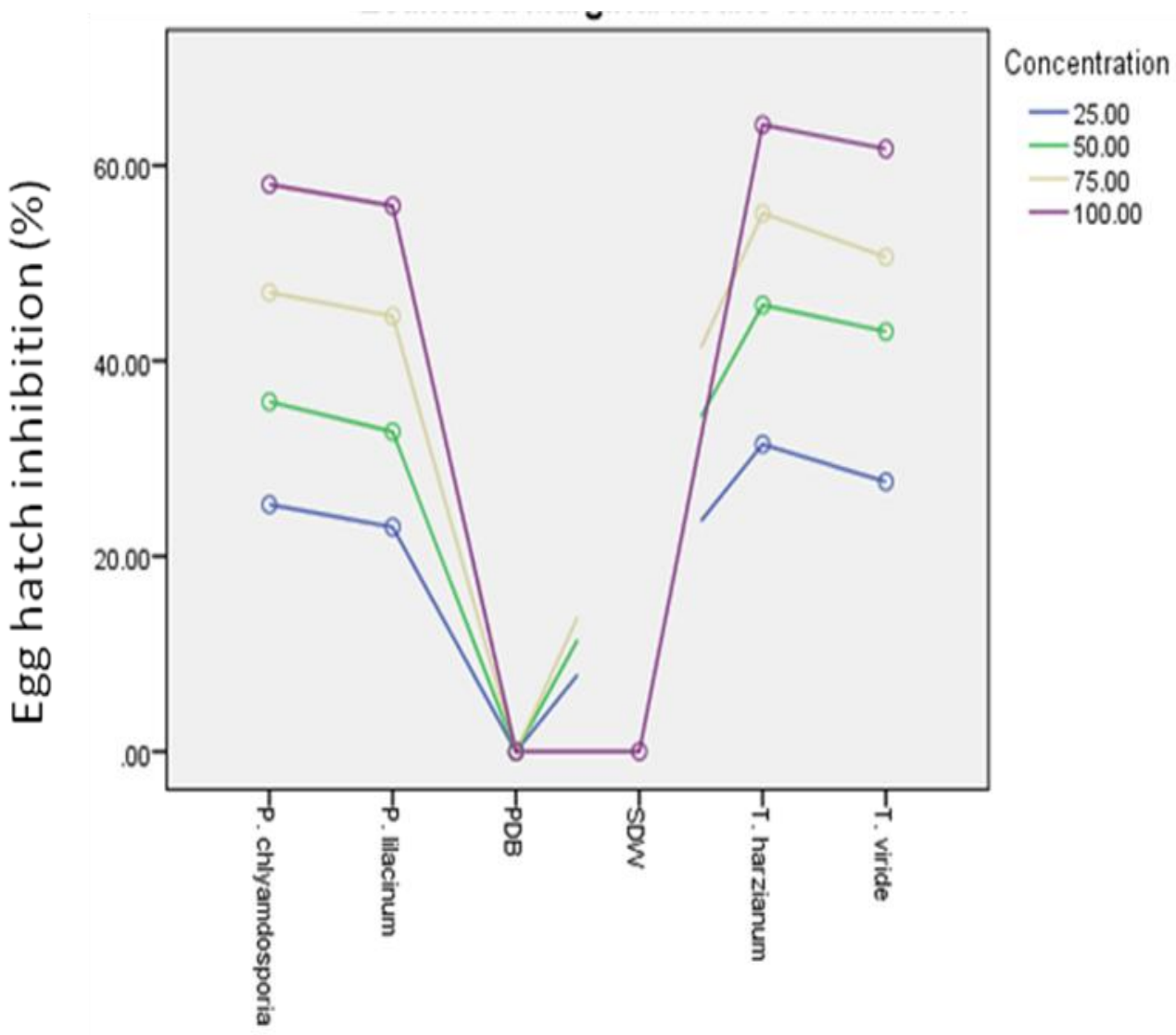

Treatments 
Fig.4 Effect of culture filtrates of fungal bioagents on the mortality of $M$. incognita $\mathrm{J}_{2}$ in 25,50 , 75 and 100percent concentration at 24, 48, 72 and 96hrs of exposure time
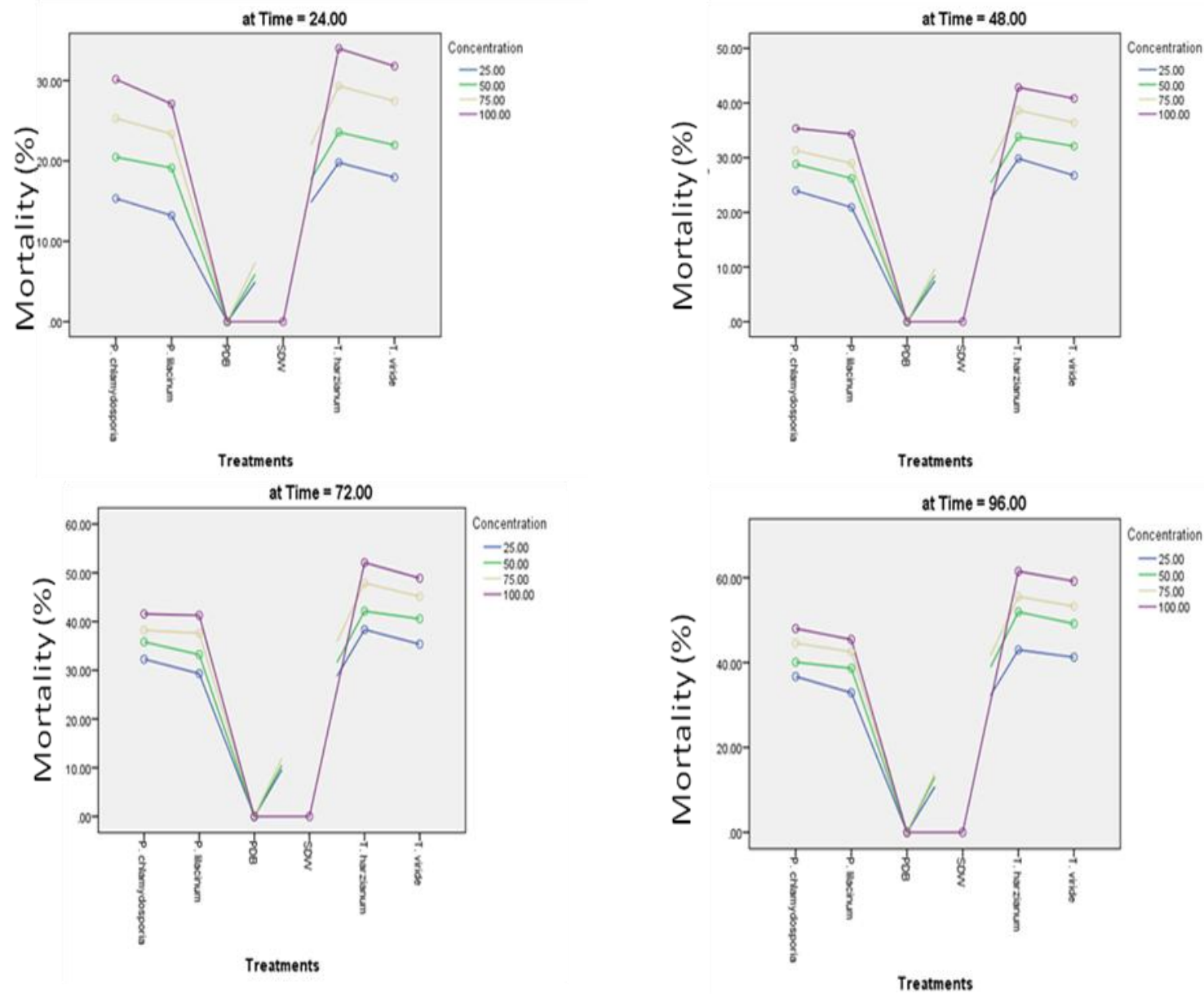

Table.1 Effect of fungal bioagents on the parasitism of $M$. incognita eggs

\begin{tabular}{|l|c|}
\hline Treatments & Egg parasitism (\%) \\
\hline T. viride & $47.20(43.39)^{\mathrm{c}}$ \\
\hline T. harzianum & $40.40(39.46)^{\mathrm{d}}$ \\
\hline P. chlanydosporia & $86.00(68.03)^{\mathrm{a}}$ \\
\hline P. lilacinum & $81.40(64.45)^{\mathrm{e}}$ \\
\hline Control & $0.0(0.0025)^{\mathrm{b}}$ \\
\hline S.Ed $( \pm)$ & 0.40 \\
\hline C.D. $(0.05)$ & 0.85 \\
\hline
\end{tabular}

The value in the parenthesis are arc sin transformation before analysis

Mean with different letters in the column are significantly different from each other based on Duncan's Multiple Range Test (C.D. at 0.05). 
Table.2 Effect of culture filtrates of fungal bioagents on the hatching inhibition of $M$. incognita eggs

\begin{tabular}{|l|c|c|c|c|}
\hline \multicolumn{1}{|c|}{ Treatments } & \multicolumn{2}{|c|}{ Concentrations } & $\mathbf{1 0 0 \%}$ \\
\hline & $\mathbf{2 5 \%}$ & $\mathbf{5 0 \%}$ & $\mathbf{7 5 \%}$ & 77.50 \\
\hline T. viride & 21.50 & 46.50 & 59.67 & $(61.69)$ \\
\hline & $(27.61)$ & $(42.99)$ & $(50.62)$ & 81.00 \\
\hline T. harzianum & 27.25 & 51.25 & 67.25 & $(64.16)$ \\
\hline P. chlaumydosporia & $(31.45)$ & $(45.71)$ & $(55.09)$ & 72.00 \\
\hline & 18.25 & 34.25 & 53.50 & $(58.05)$ \\
\hline P. lilacinum & $(25.28)$ & $(35.81)$ & $(47.00)$ & 68.50 \\
& 15.25 & 29.25 & 49.25 & $(55.86)$ \\
\hline PDB & $(22.97)$ & $(32.73)$ & $(44.57)$ & - \\
\hline
\end{tabular}

\begin{tabular}{|c|c|c|c|}
\hline Factors & F value & $d f$ & P value \\
\hline Treatment & 18876.86 & 5 & 0.0001 \\
\hline Concentration & 4788.08 & 3 & 0.0001 \\
\hline Treatment $\times$ Concentration & 487.55 & 15 & 0.0001 \\
\hline
\end{tabular}


Table.3 Effect of culture filtrates of fungal bioagents on the mortality of $M$. incognita $\mathrm{J}_{2}$

\begin{tabular}{|c|c|c|c|c|c|c|c|c|c|c|c|c|c|c|c|c|}
\hline \multirow[t]{3}{*}{ Treatments } & \multicolumn{16}{|c|}{ Concentrations } \\
\hline & \multicolumn{4}{|c|}{$25 \%$} & \multicolumn{4}{|c|}{$50 \%$} & \multicolumn{4}{|c|}{$75 \%$} & \multicolumn{4}{|c|}{$100 \%$} \\
\hline & $24 \mathrm{hrs}$ & 48hrs & $72 \mathrm{hrs}$ & 96hrs & $24 \mathrm{hrs}$ & 48hrs & $72 \mathrm{hrs}$ & 96hrs & $24 \mathrm{hrs}$ & 48hrs & $72 \mathrm{hrs}$ & 96hrs & 24hrs & $48 \mathrm{hrs}$ & $72 \mathrm{hrs}$ & 96hrs \\
\hline T. viride & $\begin{array}{c}9.50 \\
(17.95)\end{array}$ & $\begin{array}{c}20.25 \\
(26.74)\end{array}$ & $\begin{array}{c}33.50 \\
(35.36)\end{array}$ & $\begin{array}{c}43.50 \\
(41.26)\end{array}$ & $\begin{array}{l}14.00 \\
(21.97)\end{array}$ & $\begin{array}{c}28.25 \\
(32.10)\end{array}$ & $\begin{array}{c}42.25 \\
(40.54)\end{array}$ & $\begin{array}{c}57.25 \\
(49.17)\end{array}$ & $\begin{array}{l}21.25 \\
(27.45)\end{array}$ & $\begin{array}{c}35.25 \\
(36.42)\end{array}$ & $\begin{array}{c}50.25 \\
(45.14)\end{array}$ & $\begin{array}{c}64.25 \\
(53.28)\end{array}$ & $\begin{array}{c}27.75 \\
(31.78)\end{array}$ & $\begin{array}{c}42.75 \\
(40.83)\end{array}$ & $\begin{array}{c}56.75 \\
(48.88)\end{array}$ & $\begin{array}{c}73.75 \\
(59.18)\end{array}$ \\
\hline T. harzianum & $\begin{array}{c}11.50 \\
(19.80)\end{array}$ & $\begin{array}{l}24.75 \\
(29.83)\end{array}$ & $\begin{array}{c}38.50 \\
(38.35)\end{array}$ & $\begin{array}{c}46.50 \\
(42.99)\end{array}$ & $\begin{array}{c}16.00 \\
(23.57)\end{array}$ & $\begin{array}{c}31.00 \\
(33.83)\end{array}$ & $\begin{array}{c}45.00 \\
(42.13)\end{array}$ & $\begin{array}{c}62.00 \\
(51.94)\end{array}$ & $\begin{array}{l}24.00 \\
(29.33)\end{array}$ & $\begin{array}{c}39.00 \\
(38.64)\end{array}$ & $\begin{array}{c}55.00 \\
(47.87)\end{array}$ & $\begin{array}{l}68.00 \\
(55.55)\end{array}$ & $\begin{array}{l}31.25 \\
(33.99)\end{array}$ & $\begin{array}{c}46.25 \\
(42.85)\end{array}$ & $\begin{array}{c}62.25 \\
(52.09)\end{array}$ & $\begin{array}{c}77.25 \\
(61.51)\end{array}$ \\
\hline $\begin{array}{l}P . \\
\text { chlamydosporia }\end{array}$ & $\begin{array}{c}7.00 \\
(15.32)\end{array}$ & $\begin{array}{c}16.50 \\
(23.95)\end{array}$ & $\begin{array}{c}28.50 \\
(32.26)\end{array}$ & $\begin{array}{l}35.75 \\
(36.71)\end{array}$ & $\begin{array}{l}12.25 \\
(20.48)\end{array}$ & $\begin{array}{c}23.25 \\
(28.82)\end{array}$ & $\begin{array}{c}34.25 \\
(35.81)\end{array}$ & $\begin{array}{c}41.50 \\
(40.10)\end{array}$ & $\begin{array}{c}18.25 \\
(25.28)\end{array}$ & $\begin{array}{l}27.00 \\
(31.30)\end{array}$ & $\begin{array}{c}38.25 \\
(38.20)\end{array}$ & $\begin{array}{l}49.25 \\
(44.58)\end{array}$ & $\begin{array}{c}25.25 \\
(30.16)\end{array}$ & $\begin{array}{c}33.50 \\
(35.36)\end{array}$ & $\begin{array}{c}44.00 \\
(41.55)\end{array}$ & $\begin{array}{c}55.25 \\
(48.01)\end{array}$ \\
\hline P. lilacinum & $\begin{array}{c}5.25 \\
(13.20)\end{array}$ & $\begin{array}{c}12.75 \\
(20.91)\end{array}$ & $\begin{array}{l}24.00 \\
(29.32)\end{array}$ & $\begin{array}{c}29.50 \\
(32.89)\end{array}$ & $\begin{array}{c}10.75 \\
(19.13)\end{array}$ & $\begin{array}{c}19.50 \\
(26.20)\end{array}$ & $\begin{array}{c}30.00 \\
(33.20)\end{array}$ & $\begin{array}{c}39.00 \\
(38.64)\end{array}$ & $\begin{array}{c}15.75 \\
(23.37)\end{array}$ & $\begin{array}{c}23.50 \\
(28.99)\end{array}$ & $\begin{array}{c}37.25 \\
(37.61)\end{array}$ & $\begin{array}{c}45.75 \\
(42.56)\end{array}$ & $\begin{array}{c}20.75 \\
(27.09)\end{array}$ & $\begin{array}{l}31.75 \\
(34.29\end{array}$ & $\begin{array}{c}43.50 \\
(41.26)\end{array}$ & $\begin{array}{c}50.75 \\
(45.43)\end{array}$ \\
\hline PDB & - & - & - & - & - & - & - & - & - & - & - & - & - & - & - & - \\
\hline SDW & & & & & & & & & & & & & - & - & - & - \\
\hline Factor & & f value & & $d f$ & $P$ value & Factor & & & & & & f value & & $d f$ & $\begin{array}{l}P \\
\text { value }\end{array}$ & \\
\hline Treatment & & 70980.53 & & 5 & 0.0001 & Treatm & ent $\times$ Time & & & & & 1403.64 & & 15 & $\begin{array}{l}0.000 \\
1\end{array}$ & \\
\hline Time & & 13216.98 & & 3 & 0.0001 & Time $x$ & Concentra & ation & & & & 13.57 & & 9 & $\begin{array}{l}0.000 \\
1\end{array}$ & \\
\hline Concentration & & 4598.42 & & 3 & 0.0001 & Treatm & ent $\times$ Conc & entration & Time & & & 7.14 & & 45 & $\begin{array}{l}0.000 \\
1\end{array}$ & \\
\hline $\begin{array}{l}\text { Treatmentx } \\
\text { Concentration }\end{array}$ & & 474.95 & & 15 & 0.0001 & “-” indi & icate no $\mathrm{J} 2$ & mortality & The valu & in the par & nthesis a & $\operatorname{arc} \sin$ tran & isformati & $\mathrm{n}$ before a & alysis & \\
\hline
\end{tabular}


Table. $4 \mathrm{LC}_{50}$ values and relative toxicity of culture filtrates of fungal bioagents to $M$. incognita $\mathrm{J}_{2}$ after 24 hrs of exposure

\begin{tabular}{|l|c|c|c|c|c|c|c|c|}
\hline \multicolumn{1}{|c|}{ Bioagents } & Time & LC 50 Value & $\begin{array}{c}\text { Heterogeneity } \\
\left(\mathbf{R}^{2}\right)\end{array}$ & $\begin{array}{c}\text { Regression } \\
\text { equation } \\
\text { toxicity }\end{array}$ & $\begin{array}{c}\text { Fiducial limit } \\
\text { Rank }\end{array}$ \\
\hline T. harzianum & 24 & 409.145 & 1.568 & Y=0.727x-1.898 & $224.678-1665.669$ \\
\hline T. viride & 24 & 473.232 & 1.103 & Y=0.156x-1.983 & $250.161-2109.804$ & 84.46 \\
\hline P. chlamydosporia & 24 & 454.478 & 0.935 & Y=0.829x-2.204 & $253-1615.245$ & 90.02 \\
\hline P. lilacinum & 24 & 542.805 & 0.752 & Y=0.839x-2.294 & $286.943-2212.619$ & 75.38 \\
\hline
\end{tabular}

$\mathrm{Y}=$ Probit Kill, $\mathrm{X}=\log$ dose. Mortality based on 4 replications each with $100 \mathrm{~J}_{2}$ of $M$. incognita.

Table.5 LC $_{50}$ values and relative toxicity of culture filtrates of fungal bioagents to M. incognita $\mathrm{J}_{2}$ after 48 hrs of exposure

\begin{tabular}{|c|c|c|c|c|c|c|c|}
\hline Bioagents & Time & LC $_{50}$ Value & $\begin{array}{l}\text { Heterogeneity } \\
\qquad\left(\mathbf{R}^{2}\right)\end{array}$ & $\begin{array}{l}\text { Regression } \\
\text { equation }\end{array}$ & Fiducial limit & $\begin{array}{l}\text { Relative } \\
\text { toxicity }(\%)\end{array}$ & Rank \\
\hline T. harzianum & 48 & 229.313 & 0.819 & $Y=0.573 x-1.353$ & $138.041-929.436$ & 100 & 1 \\
\hline T.viride & 48 & 250.599 & 0.517 & $Y=0.634 x-1.522$ & $152.035-875.987$ & 91.51 & 2 \\
\hline P. chlamydosporia & 48 & 559.291 & 0.607 & $Y=0.530 x-1.456$ & $241.027-9296.985$ & 41.00 & 4 \\
\hline P. lilacinum & 48 & 478.208 & 0.909 & $Y=0.642 x-1.720$ & 237.744-3046.486 & 48.07 & 3 \\
\hline
\end{tabular}

$\mathrm{Y}=$ Probit Kill, $\mathrm{X}=\log$ dose. Mortality based on 4 replications each with $100 \mathrm{~J}_{2}$ of $M$. incognita. 
Table.6 $\mathrm{LC}_{50}$ values and relative toxicity of culture filtrates of fungal bioagents to $M$. incognita $\mathrm{J}_{2}$ after 72 hrs of exposure

\begin{tabular}{|c|c|c|c|c|c|c|c|}
\hline Bioagents & Time & $\mathrm{LC}_{50}$ value & $\begin{array}{c}\text { Heterogeneity } \\
\left(\mathbf{R}^{2}\right)\end{array}$ & $\begin{array}{c}\text { Regression } \\
\text { equation }\end{array}$ & Fiducial limit & $\begin{array}{c}\text { Relative } \\
\text { toxicity }(\%)\end{array}$ & Rank \\
\hline T.viride & 72 & 119.499 & 0.442 & $Y=0.572 x-1.189$ & 86.286-262.319 & 76.06 & 2 \\
\hline P. lilacinum & 72 & 284.445 & 0.810 & $Y=0.533 x-1.307$ & $155.575-1839.866$ & 31.95 & 3 \\
\hline
\end{tabular}

$\mathrm{Y}=$ Probit Kill, $\mathrm{X}=\log$ dose. Mortality based on 4 replications each with $100 \mathrm{~J}_{2}$ of $M$. incognita.

Table. $7 \mathrm{LC}_{50}$ values and relative toxicity of culture filtrates of fungal bioagents to $M$. incognita $\mathrm{J}_{2}$ after 96 hrs of exposure

\begin{tabular}{|c|c|c|c|c|c|c|c|}
\hline Bioagents & Time & $\mathrm{LC}_{50}$ value & $\begin{array}{c}\text { Heterogeneity } \\
\left(\mathbf{R}^{2}\right)\end{array}$ & $\begin{array}{l}\text { Regression } \\
\text { equation }\end{array}$ & Fiducial limit & $\begin{array}{c}\text { Relative } \\
\text { toxicity }(\%)\end{array}$ & Rank \\
\hline T. harzianum & 96 & 29.617 & 2.060 & $Y=1.315 x-1.936$ & $24.160-34.300$ & 100 & 1 \\
\hline T. viride & 96 & 52.230 & 0.683 & $Y=0.722 x-1.240$ & $41.737-64.082$ & 56.70 & 2 \\
\hline P. chlamydosporia & 96 & 141.211 & 0.754 & $Y=0.477 x-1.026$ & $92.853-543.028$ & 20.97 & 3 \\
\hline P. lilacinum & 96 & 165.138 & 0.208 & $Y=0.544 x-1.207$ & $107.899-541.017$ & 17.93 & 4 \\
\hline
\end{tabular}

$\mathrm{Y}=$ Probit Kill, $\mathrm{X}=\log$ dose. Mortality based on 4 replications each with $100 \mathrm{~J}_{2}$ of M. incognita. 


\section{$\mathrm{LC}_{50}$ values and relative toxicity of culture filtrates of fungal bioagents to $M$. incognita $\mathbf{J}_{2}$}

Data reveal (Table 4, 5, 6 and 7) that the $\mathrm{LC}_{50}$ values of culture filtrate of $\mathrm{T}$. harzianum against $M$. incognita $\mathrm{J}_{2}$ were $409.14,229.31$, 90.89 and 29.61 per cent for the exposure period of 24, 48, 72 and $96 \mathrm{hrs}$ respectively. In case of $T$. viride the $\mathrm{LC}_{50}$ values were 473.23, 250.59, 119.49 and 52.23 percent, $P$. chlamydosporia were 454.47, 559.29, 390.02 and 141.21 and $P$. lilacinum were 542.80, $478.20,284.44$ and 165.13 percent for the exposure period of 24, 48, 72 and $96 \mathrm{hrs}$ respectively. However no $\mathrm{J}_{2}$ mortality was observed in controls.

In-vitro testing of nematode destroying fungi is an essential method for evaluating their antagonistic activity against $M$. incognita and such antagonistic fungi produced metabolites and/ or protease enzymes that affect viability of nematode (Nitao et al., 1999). Nematode egg shell is proteinaceous and chitinous in nature and act as barriers for egg parasitic fungi. To overcome these barriers, these fungal bioagents produce lytic enzymes viz., proteases, chitinases and lipases that cause break down of egg shell and facilitate egg penetration for successful establishment (Elad et al., 1982; Lorito et al., 1999; Kerry, 2000). The same mechanism(s) might be possessed by tested bioagents that may have ability to produce such type of enzymes which caused extensive network of hyphae inside the $M$. incognita eggs. Similar result were also observed by Golzari et al., (2011) while working on egg parasitism by fungal bioagents and observed conidia of $T$. harzianum to stick on the gelatinous matrix around the $M$. javanica eggs masses with prolific fungal growth inside the eggs as the germinating hyphae penetrated the egg masses for parasitization. Pau et al., (2012) in line with the present investigation demonstrated early age $M$. incognita eggs to be more susceptible to $P$. lilacinum infection than the eggs with ready to hatch. Further, they observed extensive network of hyphae of $P$. lilacinum that ramified several eggs as recorded in the present investigation as well.

However, the fact that the culture filtrates in the present investigation were free of spores and mycelia strongly implies that the compounds in the filtrates had some toxic/ antibiotic substances that were instrumental in causing egg hatch inhibition and mortality of juvenile of $M$. incognita. Further, eggs of nematode are semi-permeable in nature and due to this, nematode eggs facilitate certain molecules or ions to pass through it. So toxin had permanent adverse effect on the eggs or there appears to be physical retention of the toxins in the eggs, as hatching was not resumed on transfer of eggs in water after one day (Clark and Perry, 1988). The reason behind causing mortality of $M$. incognita $\mathrm{J}_{2}$ might be due to release of lytic enzymes by Trichoderma spp. viz., chitinases (Sharon et al., 2001), lipases (Elad et al., 1982; Sivan and Chet, 1989; Lorito et al., 1993; Baker and Griffin, 1995; Chet et al., 1997; Jansson et al., 1997 and Limon et al., 1998) and acetic acid (Blaxster and Robertson, 1998 and Jansson et al., 1997) in the filtrates that cause break down of nematode cuticle proteins (Sharon et $a l ., 2001)$. The variable effect of tested fugal filtrate on $M$. incognita was observed in the present investigation can be attributed to have ability to the production of such toxic metabolites as well as protease enzymes in the filtrates.

\section{References}

Anita B, Samiyappan R. Induction of systemic resistance in rice by Pseudomonas fluorescens against rice root knot nematode Meloidogyne 
graminicola. Journal of Biopesticides 2012; 5: 53-59.

Anonymous. Biennial Report AICRP on Nematodes in cropping systems, Department of Nematology, Jorhat, Assam, 2013; 18 .

Barker R, Griffin GJ. Molecular strategies for biological control of fungal plant pathogens. In Reuveni R, Novel approaches to integrated pest management, Lewis Publishers, Boca Raton, Florida, USA, 1995, 153.

Blaxster ML, Robertson WM. The cuticle. Free-Living and Plant Parasitic Nematodes. Perry RN, Wright, DJ. CAB International, Wallingford, England, 1998, 25-48

Cayrol JC. Biological control of Meloidogyne by Arthrobotrys irregularis. Revue de Nematologie. 1983; 6: 265-723.

Chet I, Inbar J, Hadar I. Fungal antagonists and mycoparasites. In: Wicklow DT, Söderström B (eds) The Mycota IV: Environmental and microbial relationships. Springer-Verlag, Berlin, 1997, 165-184.

Clark AJ, Perry N. The induction of permeability of egg shell of Ascaris suum prior to hatching. International Journal for Parasitology. 1988; 18: 987 990.

Elad Y, Chet I, Henis Y. Degradation of plant pathogenic fungi by Trichoderma harzianum. Canadian Journal of Microbiology. 1982; 28: 719-725.

Finney DJ. Probit Analysis. Cambridge University Press, London, 1952, 318.

Golzari H, Panjehkeh N, Ahmadzadeh M, Salari M, Sedaghati-Khoravi E. Elucidating the parasitic capabilities of Trichoderma against Meloidogyne javanica on Tomato. Insight Plant Disease. 2011; 1(1): 12-19.

Hussey RS, Janssen, GJW. Root-knot nematodes: Meloidogyne species. In: Plant Resistance to Parasitic
Nematodes (Eds): Stan JL, Cook R, Bridge J. Ed 1. CAB International, United Kingdom, 2002, 43-70.

Irving F, Kerry BR. Variation between strains of the nematophagous fungus Verticillium chlamydosporium Goddard II. Factors affecting parasitism of cyst nematode eggs. Nematologica. 1986; 32:474-485.

Jansson HB, Tunlid A, Nordbring-Hertz B. Biological control. In: Anke T, editor. Fungal biotechnology: Nematodes. Chapman and Hall, Weinheim, 1997, $38-50$.

Kalita, D. J., Bhagawati, B. and Gogoi, B. B. In-vitro efficacy of Trichoderma spp. against Meloidogyne incognita and Rhizoctonia solani. Indian Journal of Nematology. 2012; 42 (1):84-87.

Karssen G, Moens M, Perry R. (2006).Plant nematology. Ed 1. CABI, Oxfordshire, 2006, 59-90.

Kerry B R. Rhizosphere interactions and exploitation of microbial agents for the biological control of plant parasitic nematodes. Annual Review of Phytopathology. 2000; 38:423-441.

Kok CJ, Papert A, Hok-A-Hin CH. Microflora of Meloidogyne egg masses: species composition, population density and effect on the biocontrol agent Verticillium chlamydosporium (Goddard). Nematology.2001; 3: 729_ 734.

Limon MC, Pintor-Toro JA, Benitez T. Increased antifungal activity of Trichoderma harzianum transformants that over expresses a 33-kDa chitinase. Phytopathology. 1998; 89: 254-261.

Lorito M, Harman GE, Hayes C K, Broadway RM, Tronsmo A., Woo SL et al., (1993). Chitnolytic enzymes produced by Trichoderma harzianum: antifungal activity purified endochitinase and chitobiosidase. Phytopathology; 83:302307. 
Mark AJ, Christopher AD, Stefan TJ. Ecological considerations in producing and formulating fungal entomopathogens for use in insect biocontrol. BioControl. 2010; 55: 129145.

Nitao JK, Meyer SLF, Chitwood DJ. In-vitro assays of Meloidogyne incognita and Heterodera glycines for detection of nematode-antagonistic fungal compounds. Journal of Nematology.1991; 31: 172-183.

Pau CG, Leong CTS, Wong SK, Eng L, Jiwan M, Kundat FR et al., Isolation of indigenous strains of Paecilomyces lilacinus with antagonistic activity against Meloidogyne incognita. International Journal of Agriculture and Biology. 2012; 14: 197-203.

Sharon E, Bar EM, Chet I, Herrera-Estrella A, Kleifeld O, Spiegel Y. Biological control of the root-knot nematode Meloidogyne javanica by Trichoderma harzianum. Phytopathology. 2001; 91: 687-693.

Singh S, Mathur N. In vitro studies of antagonistic fungi against the root-knot nematode, Meloidogyne incognita. Biocontrol Science and Technology 2010; 20 (3): 275-282.

Singh S, Pandey R K, Goswami BK. Biocontrol activity of Purpureocillium lilacinum strains in managing root-knot disease of tomato caused by Meloidogyne incognita. Biocontrol Science and Technology. 2013; 23 (12):1469-1489.

Sivan A, Chet I. The possible role of competition between Trichoderma harzianum and Fusarium oxysporum on rhizosphere colonization. Phytopathology. 1989; 79:198-203.

Zaki F. Effect of culture filtrates of Paecilomyces lilacinus on Meloidogyne javanica. Nematologia Mediterranea. 1994; 22: 41-43.

\section{How to cite this article:}

Annapurna, M., B. Bhagawati and Kurulkar, Uday. 2018. In-vitro Efficacy of Native Fungal Bioagents against Meloidogyne incognita. Int.J.Curr.Microbiol.App.Sci. 7(11): 396-410. doi: https://doi.org/10.20546/ijcmas.2018.711.048 